(C) Group of authors, 2015

UDC 616.34-007.44-053.2-08

DOI - http://dx.doi.org/10.14300/mnnc.2015.10028

ISSN - 2073-8137

\title{
INTUSSUSCEPTION TREATMENT IN CHILDREN. SINGLE CENTER EXPERIENCE
}

\author{
Savenko M. V. ${ }^{1,2}$, Degtyar V. A. ${ }^{1}$, Barsuk A. M. ${ }^{1}$, Gladkyy A. P. ${ }^{1,2}$, Koval S. V. ${ }^{1,2}$ \\ 'Dnepropetrovsk Medical Academy, Dnepropetrovsk, Ukraine \\ 2Dnepropetrovsk Regional Children Hospital, Dnepropetrovsk, Ukraine
}

\section{РЕЗУАЬТАТЫ АЕЧЕНИЯ ИНВАГИНАЦИИ КИШЕЧНИКА У АЕТЕЙ}

\author{
М. В. Савенко ${ }^{1,2}$, В. А. Аегтярь ${ }^{1}$, А. М. Барсук' , А. П. ГАаАкий ${ }^{2}$, С. В. Коваль \\ 'Анепропетровская меАицинская акалемия, Анепропетровск, Украина \\ ${ }^{2}$ Анепропетровская областная клиническая больница, Анепропетровск, Украина
}

Studying the treatment of 822 children diagnosed with intussusception from 1995 to 2013 in the Regional Clinic Children's Hospital of Dnepropetrovsk. From 1995 to 2007, 576 children took a cure. In $506(87.8 \%)$ cases, classic conservative reduction with air was successful. Laparotomy was applied in $70(12.2 \%)$ cases. For 22 children intestine was not viable and excision was executed. Forty-eight patients had surgical reductions. In connection with the analysis results, we have been using laparoscopy more widely since 2008.

From 2008 to 2013, there were 246 patients with intussuscept. For $204(82.9 \%)$ children non-operative reduction seceded. After unsuccessful non-operative reduction, $42(17.1 \%)$ children received one more laparoscopic assisted reduction. In 25 (59.5\%) cases, an intestine was found viable. In 11 (26.2\%) cases after the reduction, laparoscopic examination showed intestine necrosis. In six (14.3\%) cases, intussusceptum was caused by the Meckel's diverticulum. In all the 17 cases laparoscopic assisted excision of the Meckel's diverticulum or nonviable intestine was performed.

When non-operative reduction fails a succeeding laparoscopic assisted intussusception combined with pneumocolon is optimal to provide a good treatment result.

Key words: intussusception, treatment, laparoscopy, outcome, children

Проведен ретроспективный анализ лечения 572 детей с острой инвагинацией кишечника, находившихся на лечении в ОДКБ г. Днепропетровска с 1995 по 2007 г. В 70 (12,2\%) случаях проведено хирургическое лечение (лапаротомия), у 22 (31,4\%) детей была выполнена резекция кишечника. У остальных 48 (68,6\%) осуществляли мануальную дезинвагинацию кишечника. На основании полученных результатов оперативного лечения - в случае неэффективной консервативной дезинвагинации использовали лапароскопический метод лечения.

Проспективный этап исследования выполнен с 2008 по 2013 г. на 246 детях с инвагинацией кишечника, у которых использовалась лапароскопия. В 204 (82,9\%) случаях проведена консервативная дезинвагинация ( $<<0,001)$. У $42(17,1 \%)$ детей после неэффективного консервативного лечения проводилось расправление инвагината под контролем лапароскопа. При этом в 25 (59,5\%) случаях кишечник был жизнеспособным. У 11 (26.2\%) детей после лапароскопической оценки был определен некроз участка кишки, входящей в инвагинат. В 6 (14,3\%) случаях причиной инвагинации был дивертикул Меккеля. У всех 17 пациентов выполнена лапароскопически ассистированная резекция сегмента нежизнеспособной кишки или дивертикула Меккеля.

Таким образом, при неэффективности консервативной дезинвагинации проведение лапароскопического вмешательства позволяет получить хорошие результаты лечения у детей с инвагинацией кишечника.

Ключевые слова: инвагинации кишечника, лечение, лапароскопия, результаты, дети

A n intussusception is the most common case of an acquired intestinal obstruction of mixed type in children. It amounts up to 70-80\% of all types of an intestinal obstruction. In addition, according to some authors it holds the second place among abdominal surgical pathologies in children $[2,4,7,10]$.
Intussusception differs from other types of a mechanical intestinal obstruction in a complete absence of blockage particularly during the first hours of the disease. It conditions some peculiar clinical aspects [6, 9].

Laparotomy is believed to be a unique gold standart of intussusception treatment in children by a 
large number of surgeons. In addition, a systematic review has showed that laparotomy is safe and effective for intussusception treatment in children (more than 70\%) [1]. In addition, a laparoscopy has the lowest level of intraoperative $(0.4 \%)$ and postoperative complications (2.9\%). The commonly accepted treatment of an intussusception is a non-operative method $[3,5,8]$.

The aim of the study was to analyze an acute intussusception treatment in children and to define the place of laparoscopy in it.

Material and Methods. Studying the treatment of 822 children, who were diagnosed with intussusception from 1995 to 2013 in the regional clinical children's hospital of Dnepropetrovsk. We have made an analysis of treatment (before the introduction of laparoscopy) of 576 children diagnosed with intussusception in the regional clinical children's hospital of Dnepropetrovsk from 1995 to 2007. In 506 cases, classic conservative reduction with air was successful. Laparotomy was applied in 70 cases $(12.2 \%)$ for 48 boys and 22 girls. An intestine resection was made for $22(31.4 \%)$ children. In the other 48 (68.6\%) cases, the intestine was found viable.

In connection with the analysis of the surgical treatment, we turned to application of laparoscopy in the cases when non-operative treatment failed. In these cases, a repeated pneumatic reduction by air-contrast enema with a laparoscopic control under endotracheal anesthesia was provided. Laparoscopy was used to define the type of the intussusception, evaluate the condition of the bowel and the procedure outcome. When the bowel was viable the treatment was completed, otherwise a microlaparotomy with a further resection and bowel anastomosis were made.

From 2008 to 2014, 246 children took treatment of intussusception. Non-operative method was successful in $204(82.9 \%)$ cases. For the rest $42(17.1 \%)$ children (26 boys and 16 girls) after the unsuccessful non-operative treatment the above-mentioned method was applied.

The age share of children who took surgery was as follows: $31(73.8 \%)$ children under a year; $9(21.4 \%)$ patients from one to six; $2(4.8 \%)$ children older than six years old.

In connection with the results of patients' admission, the palpation of the abdominal wall showed that the intussusception was located in varied zones of the abdomen. Typically, an intussusception was found in the right flank $(57.1 \%)$ and in the umbilical region $(23.8 \%)$, occasionally in the ileocecal valve area $(16.7 \%)$ and in the left flank (2.4\%).

The time of admission to hospital was very important for selecting the tactics of treatment. Children that received surgery were admitted to hospital with the following terms of the disease: not more than 12 hours from the incursion of disease $6(14.3 \%)$ children, $13-24$ hours - $10(23.8 \%)$ chil- dren, more than 24 hours from incursion of disease till the admittance to hospital - 26 (61.9\%) children.

Results and discussions. Diagnosis by pneumocolonography in $93 \%$ cases showed direct signs that proved the intussusception. Sonographic examination was successful in $88 \%$ cases.

Common conservative reduction was successful for 204 children, which is $82.9 \%$ of the diseased. For $42(17.1 \%)$ patients conservative reduction was not successful and the described above tactics of reduction under the laparoscopic control was administered (Fig. 1). 


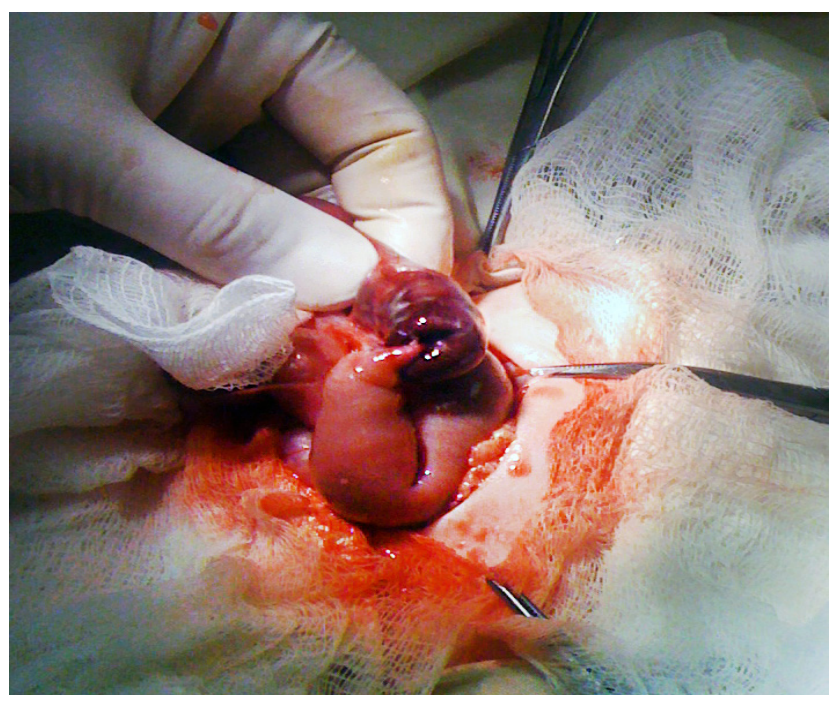

Fig. 3. Minilaparotomy in a child with Meckel's diverticulum and nonviable parts of intestine

The means of intussusception reduction is air pressure $(80-120 \mathrm{mmHg})$ in the intestine under

\section{References}

1. Apelt N., Featherstone N., Giuliani S. Laparoscopic treatment of intussusception in children: A systematic review. Journal of Pediatric Surgery 2013;48:17891793. doi: $10.1016 /$ j.jpedsurg.2013.05.024

2. Ashcraft's pediatric surgery [edited by] George Whitfield Holcomb III, J. Patrick Murphy; associate editor, Daniel J. Ostlie. $-5^{\text {th }}$ ed.

3. Bucher B. T., Hall B. L., Warner B. W., Keller M. S. Intussusception in children: cost-effectiveness of ultrasound vs diagnostic contrast enema. Journal of Pediatric Surgery 2011;46:1099-1105. doi:10.1016/j. jpedsurg.2011.03.034

4. Cheung S. T., Lee K. H., Yeung T. H. et al. Minimally invasive approach in the management of childhood intussusception. ANZ J Surg 2007;77:778-81. doi: 10.1111/j.1445-2197.2007.04228.x

5. Endoskopicheskaya hirurgiya u detey / pod redaktsiey Yu. F. Isakova, A. F. Dronova. - M.: GEOTAR-MED, 2002. conditions of miorelaxation and endotracheal anesthesia. While the laparoscopy allows to control the process of reduction and to evaluate the viability of the intestine. In connection with the analysis of the treatment, we appreciably changed our views on the selection of treatment tactics. We believe that the disease stage is not determinative for application of the conservative treatment. The key indications are the general state of a child, clinical signs of peritonitis and the completeness of obstruction.

\section{Conclusions}

1. The main methods of additional diagnosis of intussusception were the ultrasound examination and the pneumocolonography. A conservative reduction by an air enema was the method of choice and it was successful in $82.9 \%$ of cases.

2. In case of a failed conservative treatment, a laparoscopic control combined with the pneumocolon under the miorelaxation and endotracheal anesthesia was the optimal method, which allows diminishing the operative trauma and the quantity of classic laparotomies.

6. Fraser J. D., Aguayo P., Ho B. et al. Laparoscopic management of intussuscpetion in pediatric patients. J Laparoendosc Adv Surg Tech A 2009;19(4):563-565. doi: 10.1089/lap.2009.0117

7. Kirgizov I. V., Minaev S. V. The ultrasonic way of the intraoperative assess of the resection volume of colon in children with chronic constipation. Medicinskii Vestnik Severnogo Kavkaza. - Medical News of North Caucasus. 2014;9(2):125-128. doi: 10.14300/mnnc.2014.09035

8. Poddoubnyi I. V., Dronov A. F., Blinnikov O. I. et al. Laparoscopy in the treatment of intussusceptin in children. J Pediatr Surg 1998;33(8):1194-1197. doi: 10.1016/ S0022-3468(98)90149-X

9. Puri P, Höllwarth M. Pediatric surgery. Berlin, Heidelberg: Springer; 2006.

10. Takeuchi M., Osamura T., Yasunaga H. et al. Intussusception among Japanese children: an epidemiologic study using an administrative database. BMC Pediatr 2012;12:36. doi:10.1186/1471-2431-12-36

\footnotetext{
About authors:

Savenko Maksim Vladimirovich, Assistant of the Department of Pediatric Surgery Dnepropetrovsk Medical Academy, Ukraine; tel.: +380567136601; e-mail: savenko_maxim@inbox.ru
}

Degtyar Valeriy Andreevich, MD, PhD, professor, Head of the department of pediatric surgery Dnepropetrovsk Medical Academy, Ukraine; tel.: +3805671366016; e-mail: kdethyrddma@gmail.com

Barsuk Aleksandr Mikhaylovich, PhD, Clinical Associate Professor of the department of pediatric surgery Dnepropetrovsk Medical Academy, Ukraine;

tel.: +380567136601; e-mail: barsuk_a@ukr.net

Gladkiy Aleksandr Petrovich, Head of the Department of Reconstructive Surgery with Oncological beds of the Dnepropetrovsk Regional Children's Hospital, Ukraine; tel.: +380567136419; e-mail: gladkyy_alex@ukr.net

Koval Sergey Vasilevich, Head of the Department of Endovideosurgery with Burn injury beds of the Dnepropetrovsk Regional Children's Hospital, Ukraine;

tel.: +380567136406; e-mail: serg_doc_@ukr.net 